\title{
De humanisering van het volkenrecht
}

\author{
Citation for published version (APA):
}

Kamminga, M. T. (2001). De humanisering van het volkenrecht. Datawyse / Universitaire Pers Maastricht. https://doi.org/10.26481/spe.20010323mk

Document status and date:

Published: 23/03/2001

DOI:

10.26481/spe.20010323mk

Document Version:

Publisher's PDF, also known as Version of record

\section{Please check the document version of this publication:}

- A submitted manuscript is the version of the article upon submission and before peer-review. There can be important differences between the submitted version and the official published version of record.

People interested in the research are advised to contact the author for the final version of the publication, or visit the DOI to the publisher's website.

- The final author version and the galley proof are versions of the publication after peer review.

- The final published version features the final layout of the paper including the volume, issue and page numbers.

Link to publication

\footnotetext{
General rights rights.

- You may freely distribute the URL identifying the publication in the public portal. please follow below link for the End User Agreement:

www.umlib.nl/taverne-license

Take down policy

If you believe that this document breaches copyright please contact us at:

repository@maastrichtuniversity.nl

providing details and we will investigate your claim.
}

Copyright and moral rights for the publications made accessible in the public portal are retained by the authors and/or other copyright owners and it is a condition of accessing publications that users recognise and abide by the legal requirements associated with these

- Users may download and print one copy of any publication from the public portal for the purpose of private study or research.

- You may not further distribute the material or use it for any profit-making activity or commercial gain

If the publication is distributed under the terms of Article $25 \mathrm{fa}$ of the Dutch Copyright Act, indicated by the "Taverne" license above, 


\section{DE HUMANISERING VAN HET VOLKENRECHT}


(c) Menno T". Kamminga, Maastricht 2001

ISBN 90527831.44

Universitaire Pers Maastricht

Foto omslag: UN/DPI Photo 84927

Vormgeving en druk: Datawyse by Maastricht: 


\section{DE HUMANISERING VAN HET VOLKENRECHT}

Rede uitgesproken bij de aanvaarding van het ambt van hoogleraar in het recht, in het bijzonder het internationaal publiekrecht, aan de Universiteit Maastricht op 23 maart 2001 door

Menno T. Kamminga

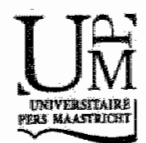




\section{MIJNHEER DE RECTOR, DAMES EN HEREN,}

Het Internationaal Gerechtshof in Den Haag maakt elk jaar een jaarverslag, dat door de President van het Hof wordt gepresenteerd aan de Algemene Vergadering van de Verenigde Naties. Meestal is dat een weinig opwindende aangelegenheid. De President van het Hof pleegt een korte samenvarting te geven van de zaken die gedurende het afgelopen jaar bij het Hof in behandeling waren. Hij pleegt zich ook in diplomatieke bewoordingen te beklagen over het geringe aantal medewerkers dar her Hof ter beschikking heeft. Een vast punt tenslotte is het uitspreken van bezorgdheid over de zogenaande proliferatie van internationale rechtscolleges. Hiermee wordt bedoeld dat er steeds meer internationale hoven en tribunalen bijkomen, die bevoegd zijn om uitspraken te doen over geschillen op onderdelen van het internationale recht.

Door de overlappende rechtsmacht van deze rechtscolleges ontstaat het gevaar van conflicterende jurisprudentie. In de nationale rechtsorde pleegt dit probleem ondervangen te worden door het creëren van een rechterlijke hiërarchie met aan het hoofd een hoogste rechtscollege dat tot taak heeft de rechtseenheid te bewaren. In het internationale recht ontbreekt een dergelijke hiërarchie. De internationale rechtscolleges staan geheel los van elkaar. Zo is er bijvoorbeeld geen beroep mogelijk van een uitspraak van het Europese Hof yoor de Rechten van de Mens in Straatsburg naar het Internationaal Gerechtshof in Den Haag.

Tot zover bekende kost. Dit gedeelre van de toespraak van de President van her Hof blijfr alrijd in algemeenheden steken. Het is immers een goede gewoonte dat rechters elkaar nier in her openbaar bekritiseren. 
In zijn toespraak tot de Algemene Vergadering in oktober van het afgelopen jaar brak de Franse rechter Gilbert Guillaume, de nieuwe President van het Internationaal Gerechtshof, met deze traditie. Tot verbazing van zijn toehoorders bekritiseerde hij met naam en toenaam een uirspraak van her Joegoslavië Tribunaal, een rechterlijke instantie die zich pikant genoeg ook in Den Haag bewindt, en wel op een steenworp afstand van het Internationaal Gerechtshof. De kritiek van Guilaume richtte zich op een vonnis van het Tribunaal in de Tadic zaak. Hierin diende het Tribunaal vast te stellen of er in de relevante periode in Bosnië-Herzegovina sprake was geweest van een internationaal gewapend conflict. Beslissend hiervoor was of sommige van de strijders in Bosnië onder commando stonden van de Joegoslavische regering in Belgrado. Het standaard arrest over een dergelijke situatie is die van het Internarionaal Gerechtshof in de Nicaragua zaak. Het Hof concludeerde in dat arrest dat de wandaden die door de zogenaamde contras waren gepleegd in Nicaragua niet aan de Verenigde Staten konden worden toegerekend. Dat was omdat de VS nier de vereiste hoge mate van controle (effective control) hadden uitgeoefend over de contras. ${ }^{2}$ Ondanks her feit dat de VS de contras hadden getraind, gefinancierd en bewapend, konden de VS dus volgens het Hof niet rechtstreeks aansprakelijk worden gesteld voor de door hen gepleegde misdrijuen.

In de Tadic zaak kwalificeerde her Joegoslavië Tribunaal het door het Internationaal Gerechtshof gehanteerde criterium van de effecrieve controle als strijdig met de logica van het recht van de staatsaansprakelijkheid. ${ }^{3}$ Volgens het Tribunaal kunnen gedagingen wan georganiseerde paramilitaire eenheden die op het grondgebied van een andere staat opereren, al aan een vreemde staat worden toegerekend als kan worden aangetoond dat zij onder de algemene controle (overall control) van die vreemde mogendheid stonden. Het is volgens het Tribunaal derhalve niet nodig dat de 
wreemde mogendheid specifieke orders heeft gegeven tot het plegen van wandaden. De afwijkende benadering van het Tribunaal stoelt kennelijk op een realistischer, door de praktijk van mensenrechtenschendingen gevoed, inzicht in de gedragingen van dergelijke militia's. ${ }^{4}$

Ook andere internationale instanties houden zich met deze controverse bezig. De International Law Commission lijkt in de meest recente versie van zijn ontwerp-artikelen over staatsaansprakelijkheid een tussenpositie in te nemen. De vereiste mate van controle wordt in deze tekst van de ILC namelijk in het midden gelaten. ${ }^{5}$

Het is vast geen toeval dat rechter Guillaume zijn pijlen richtre op het Joegoslaviê Tribunaal. Het probleem van uiteenlopende jurisprudentie doet zich ook voor bij andere deelterreinen van her internationale recht, zoals het recht van de zee, het internationaal milieurecht en het internationaal economisch recht ${ }^{6}$ maar het is her meest acuut bij de rechten van de mens. ${ }^{7}$ Op dit latitste terrein bevinden zich ook verreweg de meeste internationale rechtscolleges.

Volkenrecht is traditioneel tussen-statelijk recht. Bij de algemene leerstukken van het volkenrecht staat dan ook bescherming van de belangen van staten voorop. Onder de humanisering van het volkenrecht, het onderwerp van deze oratie, versta ik het proces waarmee het algemene deel van het internationale recht geleidelijk verandert van strikt op de bescherming van de belangen van staten gericht recht, naar een recht waarin meer gewicht wordt gegeven aan de belangen van de individuele burger. ${ }^{8}$

Toen ik eind jaren 80 aan mijn proefschrift werkte over de volkenrechtelijke aansprakelijkheid van staten voor mensentechtenschendingen heb ik mij er vaak over verbaasd dat zo weinig van hergeen in het kader van de Verenigde Naties was tot stand gebracht op het terrein van de mensenrechten, was doorgedrongen in het algemene internationale recht. Noch het Internationaal Gerechts- 
hof noch de International Law Commission leken zich erg bewust wan de toen al uitgebreide jurisprudentie van de roezichthoudende organen van de mensenrechtenverdragen.

Ook nu nog kan waak een scherp onderscheid gemaakt worden tussen degenen die zich vooral binnen het vakgebied wan de mensenrechten bewegen en degenen die het algemene volkenrecht beoefenen. ${ }^{9}$ De typische mensenrechtenjurist heeft zijn handen vol aan het op de voet volgen van de in Genève en Straatsburg (en steeds meer ook in Den Haag en Arusha) geproduceerde jurisprudentie en besluiten. Hij of zij bekommert zich weinig om het feit dat de mensentechren een onderdeel vormen van het internationale recht. ${ }^{10}$ Hierop aangesproken zullen sommige mensenrechtenspecialisten zelfs zeggen dat de mensenrechten een geheel eigen terrein vormen waarop de algemene regels van het internationale rechr feitelijk niet van toepassing zijn. ${ }^{11}$

De beoefenaar van het algemene volkenrecht, daarentegen, is geneigd de mensenrechren als een 'softe' sector wan het internationale recht te beschouwen, een onderdeel dat vooral bevolkt wordt door personen die zich nogal eens aan wishful thinking schuldig maken. Een onderdeel bovendien dat zich zo snel ontwikkelt, dat hij of zij al lang opgegeven heeft de ontwikkeling ervan bij te houden. In de algemene volkenrechtelijke handboeken is het onderdeel mensenrechren daarom vaak nogal teleurstellend. Mensenrechten zijn er nier in geïntegreerd, maar lijken er in een laat stadium aan te zijn toegevoegd. 12

Mijn eigen opvatring, dat zult $u$ inmiddels begrepen hebben, is dat de mensentechten een fundamenteel onderdeel vormen van het internationale recht, net zoals de grondrechten een basisonderdeel vormen van het nationale recht. De wisselwerking tussen de twee rechtsgebieden is fascinerend en cruciaal voor de ontwikkeling van de internationale rechtsorde. De stelling die ik u vandaag wil voorhouden is dat her relatieve gewicht van de mensenrechten de afge- 
lopen jaren zo is toegenomen, dat hierdoor de fundlamentele pijlers van her internationale recht, die soms eeuwen oud zijn, aan her wankelen worden gebracht. De internationale rechtsorde begint met andere woorden steeds meer het karakter te krijgen van een constitutionele orde waarin rechtsregels getoetst dienen te worden op hun verenigbaarheid met de fundamentele rechren van de burger.

Het toegenomen belang van de mensenrechten wordt mooi gesymboliseerd door de gebouwen van waaruit tegenwoordig gewerkt wordt. In de tijd dat. Theo van Boven, mijn ambtsvoorganger hier in Maastricht, directeur was van de mensenrechtenafdeling van de Verenigde Naties was deze club voor de nier ingewijde bezoeker nog nauwelijks te vinden. Her Mensenrechtencentrum bevond zich grotendeels ondergronds in een achteraf gelegen deel van her VN gebouw in Genève. Inmiddels is het Hoge Commissariaat voor de Mensenrechten gehuisvest in het prachtig gerenoveerde oude Volkenbondgebouw op een peperduur stukje grond pal aan her meer van Genève. Het Europese Hof voor de Rechten van de Mens heeft een vergelijkbare opwaardering ondergaan. Het is enkele jaren geleden verhuisd van een miserabel optrekje naast het eigenlijke gebouw van de Raad van Europa naar een paleis van glas en staal waar de gemiddelde multinationale onderneming zich niet voor zou schamen. Ik wil daarmee overigens geenszins verhelen dat de financiële armslag van her Hoge Commissariaat en het Europese Hof nog steeds veel te klein is.

Vandaag wil ik u meenemen op een korre rondrit langs enkele basisregels van het internationale recht. Ik zal $u$ aan de hand van drie voorbeelden laten zien dat de mensenrechten als een soort koekoeksjong bezig zijn zich in wele nesten een plaats te veroveren. 


\section{EERSTE VOORBEELD: IMMUNITEIT VAN HET STAATSHOOFD}

Volgens een van de oudste leerstukken van het internationaal recht genieten staarshoofden en andere personen die geacht worden de staat te personifiëren, zoals regeringsleiders en Ministers van Buitenlandse $\mathbb{Z}$ aken, in het buitenland immuniteit van rechrsvervolging (dar betekent dus dar zij niet strafrechtelijk vervolgd kunnen worden). Dit hangr samen met her beginsel van de soevereine gelijkheid. Omdat staten onafhankelijk en juridisch gelijk aan elkaar zijn, kan een rechter wan de ene staat geen rechtsmacht uitoefenen over (vertegenwoordigers van) een andere staat. Aan dit beginsel wordt momenteel echiter in rap tempo getornd. Dat is ook logisch, want als men aanvaardt dat het openbaar ministerie van het ene land op basis van het universaliteitsbeginsel kan optreden tegen misdrijven die in een ander لand zijn gepleegd, dan valt daarmee niet te verenigen dat vreemde staatsvertegenwoordigers zich op immuniteit zouden kunnen beroepen. Dat zouden ze immers in eigen land ook niet kunnen. 13

Een treffende illustratie vormt het arrestatiebevel dat door een Belgische onderzoeksrechter vorig jaar werd uitgevaardigd tegen de Minister van Buitenlandse Zaken van de Democratische Republiek Congo. In een op Congolees grondgebied gehouden speech zou deze Minister over 'Tutsi's hebben gesproken alls 'ongedierte' dat zou moeten worden 'uitgeroeid'. Congo heeft op dit arrestatiebevell ontstemd gereageerd. Het heeft tegen België een geschil aangespannen bij het Internationaal Gerechtshof, waarin her zich er o.a. over beklaagt dat het arrestatiebevel neerkomt op schending van de immuniteit van zijn minister. Wat het Hof hiervan zal winden is op dit moment nog nier duidelijk. ${ }^{14}$

Het is dan ook te vroeg om te concluderen dar het idee van de immuniteit van het staatshoofd inmiddels volledig is achterhaald. In 
het Handvest van het Tribunaal van Neurenberg 15 en in de Statuten van het Joegoslavië Tribunaal, ${ }^{16}$ het Rwanda Tribunaal ${ }^{17}$ en het Internationaal Strafhof ${ }^{18}$ is weliswaar vastgelegd dat staarshoofden ten overstaan van deze internationale tribunalen geen beroep kunnen doen op hun immuniteit. Maar dat betekent uiteraard nog niet dat deze regel ook van toepassing is bij berechring door een nationale rechter. In de Pinochet zaak gingen de Britse Law Lords er nog zonder meer van uit dat Pinochet volledige immuniteit genoten zou hebben indien hij op dat moment nog staatshoofd zou zijn geweest. ${ }^{19}$ En vorige week besliste her Franse Cour de cassation dat President Khadaffi van Libië in Frankrijk niet vervolgd kan worden voor zijn aandeel in het opblazen van een Frans verkeersvliegruig in 1989, omdat hij als regerend staatshoofd immuniteit van strafvervolging geniet. ${ }^{20}$ Toch beschouw ik het als significant dat Engelse en Franse rechters zich tegenwoordig genoopt zien. een regel te bevestigen, die in het verleden als volstrekt vanzelfsprekend zou zijn beschouwd.

\section{TWEEDE VOORBEELD: VOORBEHOUDEN BIJ MENSENRECHTENVERDRAGEN}

Een sleutelbeginsel van her klassieke internationale recht is dat staten in principe slechts gebonden zijn aan de verplichtingen waaraan zij hun instemming gegeven hebben. Hieruit volgt dat staten, wanneer zij partij worden bij een verdrag, kunnen besluiten een of meerdere onderdelen van dat verdrag niet te accepteren door middel van het leggen van een voorbehoud. Deze vrijheid wordt echter beperkt doordat een voorbehoud niet in strijd mag zijn met het woorwerp en doel van het verdrag. ${ }^{21}$ De essentie van een verdrag mag door een voorbehoud dus niet worden aangetast. 
In de praktijk blijkt dat bij toetreding tot mensenrechtenverdragen regelmatig voorbehouden van een zeer algemene strekking worden gemaakt. Een veel woorkomend voorbehoud is bijvoorbeeld dat de toetredende staat verklaart zich niet gebonden te achten aan verdragsbepalingen, die in strijd zijn met het Islamitisch recht of zelfs aan verdragsbepalingen, die onverenigbaar zijn met het eigen nationale recht. Staten die dit doen kunnen dus, zonder dat zij nieuwe verplichtingen op zich nemen, goede sier maken met het feit dat zij partij zijn geworden. $\mathrm{Zij}$ kunnen ook bijdragen aan de interpretatie van het verdrag, o.a. door deel te nemen aan de verkiezing van leden van het toezichthoudend comiré. De integriteit van het verdrag wordt door deze praktijk dan ook bedreigd. ${ }^{22}$

Wie bepaalt nu of een voorbehoud in strijd is met voorwerp en doel van her verdrag? En wat zijn de rechtsgevolgen van een ongeoorloofd voorbehoud? In het algemene internationale recht, zoals gecodificeerd in her Weense Verdragenverdrag, zijn het de staten die reeds eerder partij waren bij het verdrag, die individueel vaststellen of het voorbehoud in strijd is met voorwerp en doel. ${ }^{23} \mathrm{Bij}$ mensenrechtenverdragen functioneert dit systeem echrer slecht, omdat staten veelal weinig aanleiding zullen zien om bezwaar te maken regen een door een andere staat gemaakt voorbehoud. Anders dan bij bijvoorbeeld ontwapeningsverdragen, worden hun eigen materiële belangen door zo'n voorbehoud immers niet aangetast. Voor zover zij, in extreme gevallen, toch aanleiding zien om bezwaar aan te teken plegen zij daaraan meestal haastig de opmerking verbinden dat dit bezwaar niet betekent dat het verdrag niet in werking kan treden tussen de betreffende staat en henzelf. Het bezwaar is immers niet belangrijk genoeg om daarvoor de goede betrekkingen met de voorbehoudende staat op her spel te zetren.

De toezichthoudende organen van de mensenrechtenverdragen hebben zich daarom de een na de ander op het standpunt gesteld dat zij het recht hebben om vast te stellen of een voorbehoud door de 
beugel kan. Bovendien hebben zij zichzelf het recht verleend on voorbehouden die huns inziens onacceptabel zijn geheel te negeren. Het Europese Hof voor de Rechren van de Mens is hierin woorop gegaan. ${ }^{24}$ Het Mensenrechtencomité, het toezichthoudend orgaan van het VN Verdrag inzake burgerrechten en politieke rechten, is later gekomen met een zogenaamd General Comment waarin het o.a. expliciet stelt dat de relevante regels van het Weense Verdragenverdrag niet geschikt zijn om aan te geven hoe moet worden omgegaan met voorbehouden tegen mensenrechtenverdragen. ${ }^{25}$ Dit is een opmerkelijke visie, omdat bij geen enkele categorie van verdragen zo frequent woorbehouden worden gemaakt als juist bij mensenrechtenverdragen. ${ }^{26}$ Een uitzondering op het terrein van de mensenrechten tast dus de algemene regel aan.

Het valt te begrijpen dat staten, vooral staten met een slecht geweten, weinig gecharmeerd zijn van deze door de toezichthoudende organen gevolgde strategie. Het fundamentele recht van staten om zelf te bepalen aan welke verplichtingen zij zich willen onderwerpen, wordt er immers door ondergraven. De staat die het niet geaccepteerde voorbehoud maakt wordr met cen onaangename verrassing geconfronteerd. Hij blijkt meer verplichtingen te hebben aangegaan dan hij dacht geaccepteerd te hebben. De Verenigde Staten, Groot Brittannië en Frankrijk hebben dan ook uitdrukkelijk protest aangetekend tegen het General Comment van het Mensenrechtencomité: ${ }^{27}$ Andere staten daarentegen hebben her beleid van het Comité gesteund door zelf te reageren op onacceptabele voorbehouden met her standpunt dat her oorspronkelijke verdrag, d.w.z. zonder het voorbehoud, in werking treedt tussen hen en de voorbehoudende staat. ${ }^{28}$ Het Comité van Ministers van de Raad van Europa heeft hiervoor enkele alternatieve formuleringen ontwikkeld. 29

Over deze kwestie is ook een principieel conflict ontstaan tussen het Mensenrechtencomité en de International Law Commission, 
dat enigszins doet denken aan het conflict tussen het Internationaal Gerechtshof en het Joegoslaviě Tribunaal over de reikwijdte van de staatsaansprakelijkheid. De International Law Commission heeft uitdrukkelijk het standpunt ingenomen dat de regeling van her Weens Verdragenverdrag mer betrekking tot voorbehouden voldoende flexibel is om ook van toepassing te kunnen zijn op mensentechtenverdragen. ${ }^{30}$ De voorzitters van de toezichthoudende organen van de VN mensenrechtenverdragen hebben zich daarentegen nadrukkelijk achter het Mensenrechtencomité opgesteld. ${ }^{31}$ Hoe dit verschil van inzicht zal worden opgelost is op dit moment nog onduidelijk.

\section{DERDE VOORBEELD: HUMANITAIRE INTERVENTIE}

Een van de meest fundamentele pijlers van het volkenrecht, tenslotte, is het inter-statelijk geweldverbod. De Verenigde Naries is gebaseerd op de idee dat het ongeoorloofd gebruik wan geweld tussen staten tegen elke prijs voorkomen moet worden. Het Handvest van de VN kiest daarmee uirdrukkelijk voor een systeem van wat Röling negatieve vrede noemde. ${ }^{32}$ Het somt limitatief op in welke gevallen een staat geweld mag gebruiken tegen een andere staat. Kort gezegd mag dar alleen bij acute zelfverdediging of indien de Veiligheidsraad daarvoor toestemming heeft gegeven. ${ }^{33}$ Als de Veiligheidsraad het niet nodig vindt om in te grijpen kan er dus geen militaire acrie ondernomen tegen een staat die ernstige mensenrechtenschendingen begaat tegen zijn eigen burgers zonder daarbij de veiligheid van andere staten in gevaar te brengen.

De in 1999 uitgevoerde NAVO bombardementen op Joegoslavië met het doel de genocide in Kosovo een halt toe te roepen hebben echter een nieuwe impuls gegeven aan de doctrine van de 
humanitaire interventie. ${ }^{34}$ Hieronder wordt verstaan het gebruik van geweld door een of meer staten op het grondgebied van een andere staat om, zonder de instemming van die laatste staat, een einde te maken aan ernstige mensenrechtenschendingen. ${ }^{35} \mathrm{De}$ achterliggende gedachte hierbij is, dat de verplichting van staten om bijvoorbeeld genocide te voorkomen prevaleert boven het inter-statelijk geweldverbod. Nederland speelt op het ogenblik een leidende rol bij pogingen om te komen tot internationale richtijnen aan de hand waarvan bepaald kan worden of in een bepaald geval humanitaire interventie al dan niet gerechtvaardigd is. Verschillende commissies hebben over deze kwestie desgevraagd al advies uitgebracht aan de Minister van Buitenlandse Zaken. ${ }^{36}$ Minister van Aartsen heeft al het standpunt ingenomen dat er een juridische basis moet komen voor humanitaire interventie. ${ }^{37}$

Ik wil u niet verhelen dat ik sceptisch sta ten opzichte van deze exercitie. Door het introduceren van een nieuwe uitzondering op het inter-statelijk geweldwerbod zou het zorgvuldig afgewogen systeem van het Handvest van de Verenigde Naties op de helling komen te staan. Het gevaar van misbruik is m.i. erg groot indien staten expliciet zou worden toegestaan om zonder toestemming van de Veiligheidsraad militair in te grijpen indien dat naar hun oordeel uit humanitaire overwegingen noodzakelijk is. ${ }^{38}$ Het idee dat misbruik kan worden voorkomen met behulp van zorgvuldig geformuleerde criteria is volgens mij een misvatting. Hieruit blijkt dus, dat datgene wat gepresenteerd wordt onder her mom van humanisering niet automarisch als vooruitgang behoeft te worden beschouwd. De pijlers van het internationale recht zijn er niet voor niets. Zij dienen slechts na zorgvuldige overweging te worden opgeruimd. 


\section{TUSSENBALANS}

De voorbeelden die ik hier gegeven heb bevinden zich op her terrein van de staatsaansprakelijkheid, het immuniteitenrecht, het verdragsrecht en de regeling van het geweldsverbod. Hieraan zouden nog voorbeelden kunnen worden toegevoegd op het terrein van de statenopvolging 39 en de uitlevering. 40 De veranderingen voltrekken zich dus op een breed front.

Op het eerste gezicht hebben deze voorbeelden misschien weinig met elkaar gemeen. Bij nadere beschouwing blijkt echter hoe in al deze gevallen humanitaire overwegingen de grondregels van het internationale recht ter discussie stellen. Zo'n discussie leidt meestal niet tot onmiddellijke aanpassing van de grondregel, maar dat valt gezien het fundamentele karakter ervan ook niet te verwachten. Het interessante is dat het hierbij niet gaat om kleine aanpassingen van deze regels zodat zij op de lex specialis van de mensenrechten kunnen worden toegepast. Indien dat het gewal zou zijn zouden het International Gerechtshof en de International Law Commission zich niet zulke zorgen maken. Nee, regels behorende tot de lex generalis, het algemene deel van her volkenrecht, worden in de kern aangetast doordat steeds duidelijker wordt dat het op de bescherming van de belangen van staten gericht karakter ervan moeilijk te rijmen is met het verlangen de internationale rechtsorde een menselijker gezicht te geven.

\section{DRIJVENDE KRACHTEN ACHTER HET HUMANISERINGSPROCES}

Vanzelfsprekend staan staten in her algemeen niet te trappelen om hun invloed in te perken ten behoeve van de burger. Voldoende aanleiding dus om ons eens af te vragen hoe her humaniserings- 
proces in zijn werk gaar: Wie zijn eigenlijk de drijvende krachten achter dit proces? En hoe wordt hierop door staten gereageerd?

Voorop staat dat het humaniseringsproces geen enkele kans zou maken indien het niet was gebaseerd op een krachtige, wereldwijd gedeelde behoefte. Zonder die behoefte en zonder dat mensen dankzij CNN en Internet weten dat zij niet de enigen zijn met deze behoefte, zou er weinig veranderen.

Er zijn drie categorieën van actoren die een cruciale rol spelen bij] het veranderingsproces: in de eerste plaats de internationale tribunalen en de organen die toezicht houden op de naleving van mensenrechtenverdragen, in de rweede plaats de niet-gouvernementele organisaties (NGOs) en in de derde plaats verdienen de onderzoeksrechters aparte vermelding.

De internationale tribunalen en de toezichthoudende organen van de mensenrechtenverdragen plegen na verloop van enige tijd, waarin de grenzen van de eigen bevoegdheden worden afgetast, stuk voor stuk een eigen dynamiek te ontwikkelen. Gezien hun raakopdracht en de harde werkelijkheid waarmee ze dagelijks worden geconfronteerd is het begrijpelijk dat het perspectief van het individu daarbij voorop staat. De Internationale Tribunalen voor Joegoslavië en Rwanda, bijvoorbeeld, hebben de afgelopen jaren middels hun jurisprudentie een enorme impuls gegeven aan de ontwikkeling van het internationaal humanitair techt en het internationaal strafrecht.

De voortvarendheid waarmee soms te werk wordt gegaan leidt af en toe onvermijdelijk tot kritiek van de kant van staten. Ik wees hierboven al op de geërgerde reactie van sommige staten op de wijze waarop het Mensenrechrencomité met voorbehouden meent te kunnen omgaan. Maar over het algemeen zijn de tribunalen en organen er toch goed in geslaagd om de noodzakelijke steun wan de kant van de statengemeenschap niet te verspelen. 
Een tweede categorie die een belangrijke rol speelt bij het humaniseren wan de inrernarionale rechtsorde zijn de zogenaamde niet-gouvernementele organisaties. Aangezien zij zelf geen bindende besluiten kunnen nemen, kunnen NGOs de internationale rechtsvorming alleen op indirecte wijze beînvloeden. In de praktijk doen 2ij dit door te trachren invloed uit te oefenen op de uitspraken van nationale en internationale rechtscolleges en op de besluirvorming van internationale organisaties.

Bij internationale rechtscolleges worden NGOs over het algemeen niet met open armen ontvangen. $41 \mathrm{Bij}$ het Internationaal Gerechtshof bestaat de enige formele toegang tot het Hof uit de mogelijkheid om op te treden als een zogenaamde vriend van het Hof, d.w.z. om het Hof een geschreven advies aan te bieden. ${ }^{42}$ Deze mogelijkheid bestaat echter niet bij de inter-statelijke geschillenprocedure, alleen bij de zogenaamde adviesprocedure. Zelfs dan is het Hof bepaald niet scheutig met het verlenen van permissie tot het indienen van een zogenaamde amicus brief. Voor zover ik heb kunnen nagaan is dat in de praktijk slechts één maal gebeurd. ${ }^{43}$

Aanmerkelijk berere mogelijkheden voor NGO inbreng bieden het Europese en het Inter-Amerikaanse Hof woor de Rechten van de Mens. Het is than's gebruikelijk dat NGOs deze rechtscolleges schriftelijk van advies dienen wanneer er principiële kwesties aan de orde zijn. Het effect van deze adviezen is naruurlijk moeilijk vast te stellen, maar volgens sommige insiders spelen de argumenten die door NGOs worden aangedragen een belangrijke rol bij de overwegingen van de rechters. ${ }^{44}$

Amicus briefs kunnen soms ook bij de nationale rechter worden ingediend. Verschillende NGOs traden op als amici curiae bij de behandeling van de Pinochet zaak door de Britse Law Lords en het is evident dat de rechrers, die aanwankellijk niet bijster op de hoogte leken van de internationaalrechtelijke implicaties, zich door deze adviezen hebben laten inspireren. ${ }^{45}$ 
NGOs richren zich van oudsher niet alleen op de rechtszaal, maar ook en vooral ook op de conferentiezaal. Hier worden ook de spectaculairste successen geboekt. Een goed voorbeeld is het in 1997 tot stand gekomen verdrag inzake de afschaffing van landmijnen. ${ }^{46}$ De wapenbeheersing wordt traditioneel bepaald door overwegingen van nationale veiligheid, dat wil zeggen door de belangen van de staat. Er zijn wel verdragen gesloren met betrekking tot chemische en biologische wapens, maar de totstandkoming hiervan berustre niet in de eerste plaats op humanitaire overwegingen, maar vooral op de wens de verspreiding van deze wapens tegen te gaan. Het anti-landmijnen verdrag daarentegen is het eerste primair op grond van humanitaire ovenwegingen tor stand gekomen wapenbeheersingsverdrag. ${ }^{47}$ Het voornaamste argument tegen landmijnen is immers dat zij jaarlijks duizenden onschuldige slachtoffers maken. De strategische overweging dat landmijnen een noodzakelijk en goedkoop zelfverdedigingswapen zijn moest daarvoor wijken.

Het anti-landmijnenverdrag dankt zijn bestaan aan de gezamenlijk inspanningen van een aanvankelijk kleine groep $N G O$ s. Weinig NGOs zijn immers individueel sterk genoeg om op international niveau veel invloed te hebben, maar samen met anderen kan een krachtige vuist gemaakt worden. De International Campaign to Ban Landmines werd in 1992 opgericht door een kleurrijke groep van zes NGOs: Handicap International, Human Rights Watch, Medico International, Mines Advisory Group, Physicians for Human Rights en Viernam Veterans of America Foundation. 48 Inmiddels zijn bij deze coalitie meer dan $1100 \mathrm{NGOs}$ aangesloten.

Het is nauwelijks te verbazen dat de toegenomen invloed van de kant van NGOs ook weerstanden oproept. Een collega van de Universiteit van Parijs (alweer een Fransman!) heeft al geschreven over de 'excessieve' rol die NGOs speelden rijdens de conferentie in Rome over de oprichting van het Internationaal Strafhof. ${ }^{49} \mathrm{Hij}$ denkt dat het Internationaal Strafhof het risico loopt een Volkstri- 
bunaal te worden doordat NGOs er rechtstreeks toegang toe krijgen. Deze kritiek is onderdeel van meer algemene kritiek op de legitimiteir van NGOs die tegenwoordig steeds vaker valt te beluisteren. Zo wordr wel beweerd dat NGOs waak eenzijdige, soms zelfs dubieuze doelstellingen hebben; 50 en dat zij vaak weinig democratisch van structuir en aan niemand verantwoording schuldig zijn. ${ }^{51}$

Ik ben er het geheel mee eens dat NGOs niet qualitate qua als belichaming van de civil society beschouwd moeten worden. Inderclaad kan iedereen een club oprichten en zich NGO noemen. Maar rechters zullen er lijkr mij weinig moeite mee hebben om bij amicus briefs het kaf wan het koren te scheiden. Bij internationale conferenties zijn staten ook mans genoeg om een onderscheid te maken tussen respectabele en minder respectabele NGOs.

Het effect van NGOs op de internationale besluitvorming is m.i. zonder meer positief te waarderen. Het vergroot de kwaliteit van de vonnissen en besluiten doordat gebruik gemaakt kan worden van de know how van NGOs; het verhoogt het draagulak van deze vonnissen en besluiten doordat NGOs eraan hebben bijgedragen; en tenslotte levert her ook aanzienlijke besparingen op doordat NGOs hun bijdrage gratis leveren aan internationale instellingen die zichzelf vaak nauwelijks kunnen bedruipen.

Een derde en wellicht minder bekende categorie die heeft bewezen een belangrijke rol te kunnen spelen bij de humanisering van het internationale recht, met name het internationale strafrecht, wordt gevormd door de onderzoeksrechters, de juges d'instruction. Onderzoeksrechters opereren onafhankelijk van de uitvoerende macht ${ }^{52}$ en hun activiteiten worden door de eigen regering niet altijd op prijs gesteld.

Een bekend woorbeeld is de Spaanse onderzoeksrechter Baltasar Garzón die een verzoek om uitlevering tekende voor Senator Augusto Pinochet, kennelijk tegen de zin van de Spaanse regering. Deze actie leidde uiteindelijk nier tot uitlevering van Pinochet, maar 
wel tot de belangrijke uitspraak van het Britse House of Lords dat een voormallig buitenlands staatshoofed in beginsel in het Verenigd Koninkrijk geen immuniteit geniet en dus vervolgd kan worden wegens foltering. ${ }^{53}$ In België wordt een vergelijkbare rol gespeeld door de Brusselse onderzoeksrechter Damien Vandermeersch. Dit was de functionaris die her arrestatiebevel uitvaardigde tegen de Congolese Minister van Buitenlandse Zaken. ${ }^{54}$ In Senegal vinden we de onderzoeksrechter Demba Kanji, die de voormalige presidenr van Chad, Hissène Habré, onder huisarrest en in staat van beschuldiging stelde wegens medeplichtigheid aan foltering. Drie dagen geleden besliste her Senegalese Cour de cassation overigens dat Habré niet in Senegal kan worden berecht wegens in het buitenland gepleegde foltering, omdat de Senegalese wetgeving daarvoor geen rechtsbasis biedt. 55

\section{SLOTOPMERKINGEN}

Het humaniseringsproces in het internationale recht, waarvan ik hier enkele voorbeelden heb gegeven, heeft een weinig samenhangend karakter. Er gebeurt van alles op allerlei fronten, en het is niet gemakkelijk om er grip op te krijgen. De internationale gemeenschap kent niet zoiets als een grondwetsherziening met behulp waarvan de positie van de mensenrechten in de internationale rechtsorde op een systematische wijze kan worden heroverwogen. Er is ook geen internationale constirutionele rechter, die in concrete gevallen internationale rechtsregels kan toetsen aan de mensenrechten. Allerlei internationale organen op het terrein van de mensenrechten voelen zich daarom genoopt om, vanuit hun gespecialiseerde taakopdracht, een dergelijke toetsing te verrichten.

Leidt dit inderdaad tot chaos in de internationale jurisprudentie? Jonathan Charney heeft enkele jaren geleden, in de Haagse 
Acadernie voor International Recht, een serie lezingen gewijd aan de vraag of de proliferatie van internationale techtscolleges geen bedreiging oplevert voor de samenhang van het internationale recht. Zijn conclusie was toen dat dit niet het gevall is. 56 Sindsdien hebben zich echter ontwikkelingen woorgedaan die het begrijpelijk maken dat de President van het Internationaal Gerechtshof hier toch weinig gerust op is. 57

Heeft de President van het Hof er nu verstandig aan gedaan zich zo nadrukkelijk af te zetten tegen een uitspraak van het Joegoslavië Tribunaal? Het lijkr mij dat het Hof er in het algemeen beter aan zou doen om in te spelen op de humaniseringstrend in plaats van zich ervan te distantiëren. Het Hof dient zich bewust te zijn van de handicap waaronder het moet werken, n.l. dat alleen staten toegang hebben tot zijn geschillenbeslechtingprocedure Dit brengt het risico met zich mee dat het perspectief van het individu onvoldoende onder zijn aandacht gebracht wordt. Als het Hof er niet in slaagt om dit perspectief voldoende in zijn overwegingen te betrekken, loopt het het risico links en rechts ingehaald te worden door andere internationale rechtscolleges die wel toegankelijk zijn voor individuele burgers en NGOs. Het gezag van her Hof zou hierdoor op den duur ondermijnd kunnen worden.

Aangezien rechtsvragen op het gebied van de mensenrechren niet vaak aan het Hof voorgelegd worden, krijgt het Hof niet vaak de gelegenheid om op dit terrein een eigen visie te ontwikkelen. In twee recente zaken waarin mensenrechten aan de orde waren heeft het Hof zich helaas erg terughoudend opgesteld. ${ }^{58}$ In de Oost Timor zaak weigerde het Hof gebruik te maken wan de geboden mogelijkheid zich uit te spreken over het recht op zelfbeschikking van het Oost Timorese volk. 59 In de zaak betreffende genocide in Bosnië-Herzegovina achtte het Hof zich wel bevoegd, maar het maakte geen gebruik wan de geboden gelegenheid om zich duidelijk 
uit te spreken over automatische statenopvolging met betrekking tot mensenrechtenverdragen. 60

Er zijn momenteel enkele geschillen aanhangig; die het Hof de gelegenheid geven een andere weg in te slaan. Waarsehijnlijk het belangrijkste hiervan is de zaak betreffende genocide in Bosnië-Herzegovina die een internationaal rechtscollege voor het eerst in staat stelt zich uit te spreken over staatsaansprakelijkheid voor genocide. Er ligt hier een interessant verband met de ad hoc Tribunalen voor Joegoslavië en Rwanda. Het is immers moeilijk voorstelbaar dat het Hof geheel andere criteria zou hanteren om vast te stellen of een staat genocide gepleegd heeft dan de Tribunalen gebruiken om vast te stellen of individuele functionarissen van de staat zich aan genocide schuldig gemaakt hebben. ${ }^{61}$ Zou het Hof dat wel doen, dan zou er inderdaad sprake zijn van chaos in de internationale rechtsvorming.

Een hoopgevende onrwikkeling is dat van de laatste zes rechters die de afgelopen jaren in het Hof gekozen zijn, er vier kunnen bogen op een grote praktijkervaring op her terrein van de mensenrechten. Rosalyn Higgins, de Britse rechter, was lid van het VN Mensenrechtencomité. Peter Kooijmans, de Nederlandse rechter, was Nederlands vertegenwoordiger in de VN Commissie voor de Rechten van de Mens en VN rapporteur inzake foltering. Awn Shawkat Al-Khasawneh, de Jordaanse rechter, was lid van de VN SubCommissie voor de Rechten van de Mens. Thomas Buergenthal, de Amerikaanse rechter, was lid van het Inter-Amerikaanse Hof voor de Rechten van de Mens en het VN Mensenrechtencomité. De verkiezing van deze rechters door de Algemene Vergadering en de Veiligheidsraad ${ }^{62}$ kan moeilijk anders opgevat worden dan als een indicatie dat staten niet principieel gekant zijn tegen een sterkere oriëntatie van het Hof op de mensenrechten.

Voor de wetenschapper vormt de herijking van de kernleerstukken van het volkenrecht in het licht van de mensenrechten een 
grote uitdaging. Het aardige van de mensenrechten is dat zij uitnodigen tot een voortdurende herbezinning op de grondslagen van het recht. In het nationale recht is dit een bekend verschijnsel, de beurt is nu aan het internationale recht. Ik voorspel dat de mensenrechten in de volkenrechrelijke handboeken van de toekomst steeds vaker in een van de eerste in plaars wan, zoals nu gebruikelijk, in een van de laatste hoofdstukken aan de orde zullen komen.

Het prevaleren van mensentechren boven andere internationale rechtsregels veronderstelt een zekere hiërarchische ordening in het internationale recht. De theoretische fundering hiervan staat nog in de kinderschoenen. ${ }^{63}$ Het uitgangspunt moet echter zijn dat, aangezien de mensenrechten eisen stellen aan de gezagsuitoefening door de staat, algemene regels van volkenrecht die het resultaat zijn van deze gezagsuitoefening niet in strijd mogen zijn met de mensenrechten. ${ }^{64}$

Misschien begint u zich langzamerhand af te vragen af of ik mijzelf met dit verhaal niet bezondig aan het bekende euvel van de mensenrechrenjurist, dat van wishful thinking of althans de oratio pro domo. Leiden de door mij geschetste ontwikkelingen alleen tot verbeteringen op papier of ook tot verbeteringen in de praktijk? Ik denk dat er wel degelijk ingrijpende veranderingen plaats vinden die verder reiken dan het geduldige papier. Te verwachten valt bijvoorbeeld, dat op den duur wel degelijk een preventief effect zal uitgaan van het feit dat staarshoofden er niet langer geheel zeker van kunnen zijn dat zij in het buitenland niet vervolgd zullen worden. Voor zover het volkenrecht nog het karakter heeft van een samenzwering van de machthebbers, wordt dit door het humaniseringsproces onherroepelijk ondergraven.

Enige relativerende opmerkingen dienen hierbij echter wel gemaakt te worden. In de eerste plaats dient bij het her-ijkingsproces de nodige voorzichtigheid te worden betracht. Zoals ik al opmerkte bij de plotseling gegroeide populariteit van de humanitaire inter- 
ventie, moeten de grondbeginselen wan het internationale vecht niet zonder goede redenen overboord worden gezet.

In de tweede plaats is hwmanisering niet de enige of zelfs maar de woornamste tendens in de wereldgemeenschap. Een terminste even belangrijke trend is de globalisering van de wereldeconomie, die vergezeld gaat van deregulering en privatisering van overheidsfuncties, als gevolg waarvan de positie wan de staat wordt verzwakt. Dit is dus een trend die haaks staat op de humanisering, die juist een grorere regeldichtheid en een sterke rol wan de staat bij de handhaving van die regels met zich meebrengt. Een belangrijk terrein van onderzok berreft dan ook het te bereiken evenwicht ussen globahsering en humanisering. 


\section{DANKWOORD}

Ik dank het College van Bestuur en het Bestuur van de Faculteit der Rechtsgeleerdheid van de Universiteit Maastricht woor het in mij gestelde vertrouwen. Dat klinkt obligaat; maar ik heb vaak genoeg aan de andere kant van de streep gestaan om te beseffen welke risico's aan zulke benoemingen kleven.

Ik zal mijn best doen deze leerstoel voort te zetten in de traditie van Theo van Boven, dat wil zeggen met een mengsel van wetenschap en maatschappelijk activisme op het allerhoogste niveau. De Universiteit Maastricht geniet een wereldwijde reputatie op het terrein van het internationale recht in her algemeen en de mensenrechten in het bijzonder en dat is voor een groot deel de verdienste van Theo van Boven. Theo, het is een groot genoegen je ook na je emeritaat nog zo regelmatig in de faculteit te zien en ik hoop dar dir nog lang zo zal blijven.

Ik heb een hartgrondige hekel aan het cliché van de 'leermeesters' die aan het eind van een oratie ten tonele plegen te worden gevoerd. I $k$ wil hier echter wel de namen noemen van twee hoogleraren die mij ten voorbeeld zijn geweest: B.V.A. Röling, die mij begin jaren 70 in Groningen op het spoor zette van de humanisering van het volkenrecht en Peter Kooijmans, mijn promotor, die al in 1965 een oratie uitsprak onder de titel 'Volkenrecht en sociale gerechtigheid'.

Collega's van de onderzoekschool Rechten van de Mens, ik verheug mij op voortzetting van de nu reeds uitstekende samenwerking. Als opletrende lezers van de beleidsstukken van de onderzoekschool zal het u ongetwijfeld opgevallen zijn, dat ik met mijn verhaal vandaag een voorzet heb trachten te geven voor de bestudering wan thema 1 van de her-erkenningsaanvraag.

Collega's van de capaciteitsgroep Internationaal en Europees Recht en het Maastrichtse Centrum voor de Rechten van de Mens, ik dank jullie voor de open armen waarmee jullie mij ontvangen 
hebben. Het is een voorrecht met zo'n gemotiveerde groep mensen te mogen samenwerken. Jullie gastrijheid heeft de curiositeiten van het OG gebouw, zoals de beperkte openingstijden 's avonds en de gemengde toiletten, snel doen vergeten.

Studenten, het doet mij veel plezier dat zo veel van jullie hier vandaag aanwezig zijn. Het aardige van het internationale recht is dat nooit uitgelegd hoeft te worden waarom het zo'n fascinerend vakgebied is. Her openslaan van een willekeurige krant maakt dat meteen duidelijk. Sleutelen aan de internationale rechrsorde is voor een jurist een van de meest bevredigende bezigheden die er is. Er is nog veel werk aan de winkel en ik zal jullie daarbij graag op het goede spoor helpen.

Openbare liefdesbetuigingen zijn in mijn familie niet de gewoonte. Dat laten wre graag over aan de commerciële omroep. Het doet mij echter heel war mijn ouders vandaag glunderend op de eerste rij te zien zitten. Ik hoop dat jullie in mijn opmerkingen vandaag iets herkend hebben van de discussies die we vroeger altijd aan de keukentafel hadden.

Marie-Claire, Floor en Thomas, ik realiseer me dat onze verhuizing naar Maastricht voor jullie niet altijd even gemalkkelijk is geweest. Ik ben blij dat alles langzamerhand op zijn pootjes rerecht aan het komen is. En Floor, morgen, als papa zijn jurk in de kast gehangen heeft, zal hij weer iets leukers gaan voorlezen.

Ik heb gezegd. 
1 Address by Judge Gilbert Guillaume to the United Nations General Assembly, 26 October 2000, www.icj-cij.org.

2 International Court of Justice, Military and Paramilitary Activities in and Against Nicaragua, Judgmenr of 27 June 1986, ICJ Reports 1986, par. 115.

3 International Criminal Tribunal for the Former Yugoslavia - Appealls Chamber, Prosecutor v. Tadic, Judgment of 5 July 1999, 38 ILM (1999) 1518, par. 115-145.

4 Zie over de internationaalrechtelijke aansprakelijkheid van gewapende oppositiegroepen Liesbeth Zegveld, Amed Oppostion Groups in International Law: The Quest for Accountability (2001).

5. Art. 6 van de Draft articles provisionally adopted by the Drafting Committee on second reading (UN Doc. A/CN.4/L.600) luidt als volgt: "The conduct of a person or group of persons shall be considered an act of the State under international law if the person or group of persons was in fact acting on the instructions of, or under the direction or control of, that State in carrying out the conduct.' (mijn cursivering).

6 Zie Benedict Kingsbury, 'Foreword: Is the Proliferation of International Courts and Tribunals a Systemic Problem?' 31 New York University Joumal of International Law and Politics (1999) 679 alsmede de overige artikelen in deze aflevering van het tijdschriff. 
Zie ook Ellen Hey, Reflections on an Intermational Environmental Cownt, oratie Rotterdam (2000) 9-14.

7 De volgende dag, in een toespraak voor de Zesde (Juridische) Commissie van de Algemene Vergadering, zette Guillaume ook vraagtekens bij de uirspraak van het Europese Hof voor de Rechren van de Mens in de Loizidou zaak (zie hieronder, noot 24). Speech by the President of the International Court of Justice to the Sixth Commitree of the UN General Assembly, 27 October 2000, www.icj-cij.org.

8 De term 'humanisering van het volkenrecht' ontleen ik aan Theodor Meron, 'The Humanization of International Humanitarian Law', 94 AJIL (2000) 239-278. Flinterman wijdde zijn oratie vorig jaar aan de stelling dat humaniteit boven soevereiniteit gaat. C. Flinterman, Soevereiniteit en de rechten van de mens, oratie Utrechr (2000).

9 Zie Bruno Simma, 'International Human Rights and General International Law: A Comparative Analysis', in: Collected Courses of the Academy of European Law vol. IV/2 (1993) 153, 163-165.

10 Zie Gilbert Guilaume, 'La Cour internationale de justice: Quelques propositions concrètes à l'occasion du Cinquantenaire', RGDIP 1996-2, 23, 331.

11 Vergelijk bijwoorbeeld de visie van Clapham dat het leerstuk van de staatsaansprakelijkheid nier van toepassing is op schendingen in het kader van het EVRM: Andrew Clapham; Human Rights in the Private Sphere (1993) 188. Voor een systematische kritiek op deze opvatting, zie R.A. Lawson, Het EVRM en de Europese Gemeenschappen (1999) 217-263. 
12 Gunstige uitzonderingen zijn bijvoorbeeld Verdross/Simma, Universelles Völkerecht (3d. ed. 1984); Cassese, International Law in a Divided World (1986); en Schachter, International Law in Theory and Practice (1991).

13 Zie Andrea Bianchi, "Immunity versus Human Rights: The Pinochet Case', 10 EJIL (1999) 237, 276-277.

14 Op 8 december 2000 weigerde het Hof de door Congo gevraagde voorlopige maatregelen te treffen, aangezien de betreffende Minister inmiddels Minister van Onderwijs geworden was. Hierdoor was de urgentie van de zaak volgens het Hof verdwenen. International Court of Justice, Case Concerning the Arrest Warrant of 1 April 2000 (Democratic Republic of the Congo v. Belgium), Order of 8 December 2000, par. 72. Gezien de zich verbeterende betrekkingen tussen Congo en België zal dit geschil vermoedelijk te zijner tijd geschikt worden en dus niet tot een inhoudelijke uitspraak van het Hof leiden.

15 Art. 7, Handvest van het Tribunaal van Neurenberg, 88 UNTS 280.

16 Art. 7(2), Statuut van het Joegoslavië Tribunaal, 32 ILM (1993) 1159.

17 Art. 6(2), Statuut van het Rwanda Tribunaal, 33 ILM (1994) 1598.

18 Art. 27(1), Statuut wan her Internationaal Strafhof, 37 ILM (1998) 999.

19 UK House of Lords, Regina v. Bartle and the Commissioner of Police for the Metropolis and Others ex Parte Pinochet, Judgment of 24 March 1999, 38 ILM (1999), 581, 592, 597, 621, 628, 642, 644, 653 .

20 Le Monde, 13 maart 2001. 
21 Art. 19, Verdrag van Wenen inzake het verdragenrecht, 23 mei 1969, Trb. 1985, 79.

22 Zie hierover Liesbeth Lijnzaad, Reservations to UN-Human Right Treaties: Ratify and Ruin? (1994).

23 Art. 20(4), Weens Verdragenverdrag, hierboven noot 21.

24 European Court of Human Rights, Belilos v. Switzerland, Judgment of 9 April 1988, Series A 132, par. 60; Loizidou v. Turkey (preliminary objections), Judgment of 23 March 1995, Series A 310, par. 97.

25 Human Rights Commitree General Comment 24 (52), 2 November 1994, 34 ILM (1995) 839, par. 17-18. Her is interessant dat het eerste ontwerp van dit General Comment werd opgesteld door Rosalyn Higgins, toentertijd lid van het Mensenrechtencomite, thans rechter in het Internationaal Gerechrshof. Voor commentaar zie bijvoorbeeld Carherine J. Redgwell, 'Reservations to Treaties and Human Rights Committee General Comment No.24(52)’, 46 ICLQ (1997) 390-412.

26 Bruno Simma, 'Reservations to Human Rights Treaties - Some Recent Developments', in: G. Hafner et al. (eds.), Liber Amicorum Ignaz Seidl-Hahenveldern (1998) 659, 660.

27 Teksten gereproduceerd in de Appendix van J.P. Gardner (ed.), Human Rights as General Norms and a State's Right to Opt out: Reservations and Objections to Human Rights Conventions (1997).

28 Het zijn vooral de Noordse landen die hierin een pioniersrol vervullen. Zie Jan Klabbers, 'Accepting the Unacceptable? A New Nordic Approach to 
Reservations to Multilateral Treaties', 69 Nordic Joumal of International Law (2000) 179-193.

29 Committee of Ministers Recommendation No. R (99)

13 on Responses to Inadmissible Reservations to International Treaties, 18 May 1999, www.coe.int.

30 Preliminary Conclusions of the International Law Commission on Reservations to Normative Multilateral Treaties Including Human Righrs Treaties, 1997 ILC Report, UN Doc. A/52/10, par. 157.

31 UN Doc. A/53/125, par. 18.

32 B.V.A. Röling, Volkenrecht en vrede, $3^{e}$ druk (1985) 18-19.

33 Art. 51 en 42, Handvest van de Verenigde Naties.

34 Zie bijvoorbeeld de discussie in 93 AJIL (1999) 824-862 en 10 EJIL (1999) 1-30.

35 Over humanitaire interventie bestaat een uitgebreide literatuur. Een van de beste overzichten biedt Peter Malanczuk, Humanitarian Intervention and the Legitimacy of the Use of Force, oratie Amsterdam (1993).

36 Adviesraad Internationale Vraagstukken en Commissie van Advies inzake Volkenrechtelijke Vraagstukken, Humanitaire Interventie, Advies No. 13, april 2000.

37 Speech door Minister J.J. van Aartsen tijdens een seminar over humanitaire interventie georganiseerd door de International Peace Academy, New York, 20 november 2000 , www.minbuza.nl.

38 Zie in kritische zin bijwoorbeeld ook Nico Schrijwer, 'Soevereiniteit versus humaniteit? Het hek raakt van de dam', Internationale Spectator (2000) 227-231. 
39 Zie Menno T. Kamminga, 'Stare Succession in Respect of Human Rights Treaties', 7 EJIL (1996) $469-484$.

40 Zie John Dugard \& Christine van den Wyngaert, 'Reconciling Extradition with Human Rights' $92 \mathrm{AJIL}$ (1998) 187-212.

41 Zie Diana Shelton, "The Participation of Nongovernmental Organizations in Internarional Judicial Proceedings", 88 AJIL (1994) 611-642.

42 Art. 66, Statuut Internationaal Gerechtshof.

43 In $1950 \mathrm{kreeg}$ de International League for Human Rights toestemming voor her indienen van een advies, maar dit werd op procedurele gronden nier-ontvankelijk verklaard. Roger S. Clark, "The International League for Human Rights and South West Africa 1947-1957: The Human Rights NGO as Catalyst in the International Legal Process", 3 HRQ (1981) 116-121.

44 Marek Antoni Nowicki, 'NGOs before the European Commission and Court of Human Rights', 14 NQHR (1996) 297.

45 Zie Christine Chinkin, 'Ex Parte Pinochet', 93 AIIL (1999) 703, 704, 710.

46 Verdrag inzake het verbod van her gebruik, de anleg van voorraden, de producrie en de overdracht van anti-personeelsmijnen en inzake de vernietiging van deze wapens, Oslo, 18 september 1997, Trb. 1998, Nr. 135.

47 Robert J. Mathews en Timothy L.H. McCormack, 'The Influence of Humanitarian Principles in the Negotiation of Arms Control Treaties', International Review of the Red Cross No. 834 (1999) 331-352. 
48 Jody Williams en Stephen Goose, "The International Campaign to Ban Landmines', in: M. Cameron et al. (eds.), To Wralk without Fear: The Glabal Movement to Ban Landmines (1998) 22.

49 Serge Sur, "Vers une Cour pénale internationale: la Convention de Rome entre les ONG et le Conseil de sécuritế, 103 RGDIP (1999) 35-36.

50 Oscar Schachter, "The Decline of the Nation-State and its Implications for International Law', 36 Columbia Jownal of Transnational Law (1997) 7, 14.

51 'The Non-Governmental Order: Will NGOs Democratise, or Merely Disrupt, Global Governance?", The Economist, 11 December 1999, 18-19.

52 Pierre Chambon, Le juge d'instruction: theorie et pratique de la procédure, 3e édition (1985) 4, 77.

53 UK House of Lords, Ex Parte Pinochet, hierboven noot 19.

54 Zie hierboven noor 14.

55 Cour de cassation du Sénégal, Guengueng et autres contre Hissène Habré, 20 mars 2000, www.hrw.org/french/themes/habre-cour_de_cass.html.

56 Jonathan Charney, Is International Law Threatened by Multiple International Tribunals'? 271 Recueil des cours (1998) 101-382.

57 Bijvoorbeeld de uitspraak van het Joegoslavië Tribunaal in de Tadic zaak en de reactie van de International Law Commission op de General Comment van het Mensenrechtencomité. Hierboven noten 3 en 30.

58 Rosalyn Higgins, "The International Court of Justice and Human Rights', in K. Wellens (ed.), International Law: Theory and Practice (1998) 691, 695-697. 
59 Case concerning East Timor (Portugal v. Australia), Judgment of 30 June 1995, ICJ Reports 1995, 90, par. 30-33.

60 Case Concerning Application of the Convention on the Prevention and Punishment of the Crime of Genocide (Bosnia-Herzegovina v. Yugoslavia), Judgment of 11 July 1996 (preliminary objections), www.icj-cij.org, par. 17 and 23.

61 Zie over dit werband André Nolllkaemper, De dialectiek tussen individuele en collectieve ansprakelijkheid in bet volkenrecht, oratie Amsterdam (1999). Het Joegoslavie Tribunaal heeft overigens, anders dan het Rwanda Tribunaal, tot op heden nog geen personen veroordeeld wegens genocide.

62 Leden van het Internationaal Gerechtshof worden verkozen door de Veiligheidsraad en de Algemene Vergadering van de Verenigde Naties. Art. 4, Statuut Internationaal Gerechrshof.

63 Een voor de hand liggende redenering is dat alle mensenrechten een erga omnes karakter hebben en sommige mensenrechten bovendien jus cogens zijn. Zie hierover de recente dissertatie van Ian D. Seiderman, Hierarchy in International Law: The Human Rights Dimension (2001) 283-292.

64 Zie Matthew Craven, 'Legal Differentiation and the Concept of Human Rights Treaty in International Law', 11 EJIL (2000) 489, 519. 